\author{
Agata Rolnik, Beata Olas \\ Katedra Biochemii Ogólnej \\ Instytut Biochemii \\ Wydział Biologii i Ochrony Środowiska \\ Uniwersytet Łódzki \\ Pomorska 141/143, 90-236 Łódź \\ E-mail: agarolnik@gmail.com
}

\title{
ORZECHY LESZCZYNY POSPOLITEJ (CORYLUS AVELLANA) I JEJ INNE ORGANY JAKO BOGATE ŹRÓDŁO ZWIAZZKÓW O WŁAŚCIWOŚCIACH PROZDROWOTNYCH
}

\section{WSTEP}

Choroby układu sercowo-naczyniowego, nowotwory czy inne choroby cywilizacyjne dotykaja coraz większej liczby ludzi. Leczenie farmakologiczne nie zawsze jest wystarczające, dlatego coraz częściej poszukuje się związków o działaniu prozdrowotnym pochodzenia roślinnego. Do tej grupy należy leszczyna pospolita (Corylus avellana), przede wszystkim ze względu na jej owoce, orzechy laskowe, ale także pozostałe elementy, np. liście czy korzenie. Należy do najstarszych krzewów uprawianych przez człowieka. W starożytnej Grecji w I w. naszej ery lekarz Pedanios Dioskurydes podkreślił wykorzystanie oleju $z$ orzechów laskowych podczas leczenia przeziębień (CIEMNIEWSKA-ŻYTKIEWICZ i współaut. 2015). W Polsce od wielu lat leszczyna jest ważnym elementem medycyny ludowej. Napary $z$ liści stosowano jako leki o działaniu przeciwzapalnym, np. podczas przeziębień, czy leki na hemoroidy. Na problemy $z$ żylakami przyrzadzano herbatke $z$ tzw. kotków leszczyny pospolitej (LEWKOWICZ-Mosiej 2012). Orzechy natomiast wykorzystywane sa na całym świecie przede wszystkim do produkcji żywności, np. słodyczy czy przekasek, ale także w przemyśle farmaceutycznym i kosmetycznym (DELGADo i współaut. 2010).

\section{MORFOLOGIA LESZCZYNY POSPOLITEJ}

Corylus avellana należy do rzędu bukowców, rodziny leszczynowatych, w Polsce nazywana jest leszczyna pospolita. Jest to rozłożysty krzew rosnacy na terenie całej Europy, Ameryki Południowej i Azji. Swoim zasięgiem obejmuje całą Polskę, najrzadziej występując na terenie Podhala. Ze względu na niewielkie wymagania glebowe rośnie zarówno w lasach liściastych, mieszanych, jak i borach (MATUSZKIEWICZ i współaut. 2015). Przeciętnie osiaga wysokość od 2 do $5 \mathrm{~m}$, ale w wyjątkowo sprzyjających warunkach może urosnać do $10 \mathrm{~m}$, przede wszystkim jednak rozrasta się na szerokość. Charakteryzuje się długimi, prętowatymi gałęziami i odwrotnie jajowatymi liśćmi, o sercowatym kształcie u nasady. Owocami leszczyny pospolitej sa orzechy laskowe. Charakteryzuja się gładka, brazowa łupiną. Przeciętnie osiągają długość $2,5 \mathrm{~cm}$. Pokryte sa zielonymi, głęboko postrzępionymi okrywami. Zawieraja jedno nasienie (LEWKOWICZ-MOSIEJ 2012).

ZWIAZKI ZAWARTE W ORZECHU I POZOSTAEYCH ORGANACH LESZCZYNY POSPOLITEJ

Sto gram orzechów laskowych to aż 662 kilokalorii, z czego $60 \%$ składu stanowia tłuszcze, ale tylko $8 \%$ tej wartości 
to tłuszcze nasycone. Reszte stanowia jedno- i wielonienasycone kwasy thuszczowe, wśród których $80 \%$ stanowia jednonienasycone kwasy tłuszczowe, przede wszystkim kwas oleinowy zbudowany $z 18$ atomów węgla $z$ wiązaniem podwójnym w pozycji 9 . Pozostała część to wielonienasycone kwasy tłuszczowe. Pośród nich przeważaja kwasy zawierajace wiązanie podwójne $\mathrm{w}$ pozycji $\mathrm{n}-3$, potocznie nazywane kwasami omega-3. Należa do nich kwasy a-linolenowy oraz jego pochodne w tym kwas eikozapentaeonowy, zbudowany z 20 atomów węgla oraz kwas dokozaheksanowy, zbudowany z 22 atomów węgla (YÜCESAN i współaut. 2010, DYBKowsKa 2015). Dodatkowo, w $100 \mathrm{~g}$ orzechów znajduje się $15 \mathrm{~g}$ białka, $17 \mathrm{~g}$ węglowodanów i 9,7 g błonnika pokarmowego (Tabela 1), którego główna rola $\mathrm{w}$ organizmie człowieka jest obniżanie w surowicy poziomu lipoprotein o niskiej gęstości (ang. low density lipoproteiny, LDL) i glikemii poposiłkowej. Orzechy laskowe zawieraja duże ilości steroli i tokoferolu, przede wszystkim a-tokoferolu, ale także $\gamma^{-}$i $\beta$-tokoferolu. Zwiazki o budowie tokoferolu nazywane sa popularnie witamina E. W $100 \mathrm{~g}$ orzechów tych zawarte jest aż 33,1 mg tej witaminy (YÜCESAN i współaut. 2010, CIEMNIEWSKA-ŻYTKIEWICZ i współaut. 2014). Poza witamina E, orzechy laskowe sa bogate $\mathrm{w}$ witaminy $\mathrm{z}$ grupy $\mathrm{B}$. W 100 $\mathrm{g}$ orzechów zawarte jest około 0,64 mg tiaminy, czyli przeciętnie połowa zalecanej dziennej dawki dla dorosłego człowieka. W swoim składzie maja również naturalny

Tabela1. Skład i wartość energetyczna orzechów laskowych (wg CIEMNIEWSKA-ŻYTKIEWICZ i współaut. 2014).

\begin{tabular}{ll}
\hline Składnik orzecha laskowego & $\mathrm{g} \mathrm{w} 100 \mathrm{~g}$ orzechów \\
\hline Tłuszcze & 60 \\
Białko & 15 \\
Węglowodany & 17 \\
Błonnik pokarmowy & 9,7 \\
Witamina E & 0,033 \\
Kwas foliowy & 0,000113 \\
Tiamina & 0,00064 \\
Potas & 0,680 \\
Fosfor & 0,299 \\
Magnez & 0,163 \\
Wapń & 0,114
\end{tabular}

odpowiednik witaminy $\mathrm{B}_{9}$, znanej pod nazwa kwas foliowy. W 100 g orzechów jest $113 \mu \mathrm{g}$ kwasu foliowego (LIEW 2016, MANZARDO 2015). Zawieraja także wiele składników mineralnych. Spożycie $100 \mathrm{~g}$ dostarcza $114 \mathrm{mg}$ wapnia, $163 \mathrm{mg}$ magnezu, $290 \mathrm{mg}$ fosforu i $680 \mathrm{mg}$ potasu. Sa również źródłem aminokwasów, przede wszystkim argininy i lizyny (CIEMNIEWSKA-ŻYTKIEWICZ i współaut. 2014).

Orzechy laskowe nie sa jednym źródłem związków o działaniu prozdrowotnym $\mathrm{w}$ leszczynie pospolitej. $Z$ liści i korzeni wyizolowano wtórne metabolity nazywane diarylheptanoidami (JIRÁSEK 2014). Skórka pokrywajacca orzechy jest bogata $\mathrm{w}$ związki polifenolowe, w tym kwasy fenolowe, flawonole i flawonoidy. W twardej łupinie orzecha przeważa kwas galusowy. Około 60\% wszystkich zwiazków fenolowych w leszczynie pospolitej stanowia taniny. Pierwotnie uważano je za pozbawione właściwości prozdrowotnych, ale coraz częściej mówi się o ich aktywności antyoksydacyjnej i przeciwzapalnej (CONTINI i współaut. 2011).

\section{DZIAEANIE ANTYOKSYDACYJNE ZWIAZKOW CHEMICZNYCH W ORGANACH CORYLUS AVELLANA}

Stres oksydacyjny to stan wynikajacy $z$ braku równowagi pomiędzy wolnymi rodnikami a antyoksydantami $\mathrm{w}$ organizmie, $\mathrm{z}$ przewaga tych pierwszych. Ma bardzo niekorzystny wplyw na organizm; utrzymujacy się przez dłuższy czas powoduje wiele chorób, np. nowotwory czy choroby krażenia, dodatkowo przyśpiesza proces starzenia się organizmu. W zwiazku $z$ tym tak ważne jest dostarczanie w diecie związków o aktywności antyoksydacyjnej (DELGADO i współaut. 2010). Orzechy laskowe sa dobrym źródłem witaminy E. Spożycie około $42 \mathrm{~g}$ orzechów zaspokaja dzienne zapotrzebowanie dorosłego człowieka na tę witaminę (YÜCESAN i współaut., 2010, CiEMnIEWSKA-ŻYTKIEWICZ i współaut. 2014). Tokoferole, popularnie nazywane witamina E, charakteryzuja się silnymi właściwościami antyoksydacyjnymi ze względu na budowę strukturalna. Tworzy je dwupierścieniowy szkielet 6-chromanu oraz łańcuch boczny składajacy się z 3 jednostek izoprenowych. Grupy hydroksylowe w pierścieniu odpowiadaja za wyłapywanie wolnych rodników, tym samym nadając właściwości antyoksydacyjne (READERSTORFF i współaut. 2015). Największą aktywnością antyoksydacyjna charakteryzuje sie a-tokoferol wychwytujacy rodniki nadtlenkowe i alkoksylowe, słabsza aktywność wykazuje $\gamma$-tokoferol, ale dobrze wychwytuje reaktywne zwiazki azotu 
(READERSTORFF i współaut. 2015). Właściwości antyoksydacyjne wykazuja również zwiąki fenolowe, w tym kwas galusowy, który w orzechu wystepuje $\mathrm{w}$ twardej łupienie, oraz flawon-3-ol, który stanowi około 33 \% fenolu w leszczynie pospolitej (SLATNAR i wspó1aut. 2014). Innym rodzajem zwiąków fenolowych o silnym charakterze antyoksydacyjnym sa taniny. Chelatuja jony metali przejściowych, między innymi żelaza i miedzi. W ten sposób hamuja ich oksydację i zapobiegają powstawaniu rodników hydroksylowych (KARAMAĆ 2009). W liściach i korzeniach leszczyny pospolitej wystepuja diarylheptanoidy, wykazujące silne działanie antyoksydacyjne, wynikajace $z$ budowy strukturalnej. Obecność grupy hydroksylowej i metylowej wpływa na zdolność do wychwytywania wolnych rodników (JIRÁSEK 2014). Diarylheptanoidy zawarte w liściach leszczyny pospolitej, poza silnym działaniem antyoksydacyjnym, wykazuja działanie hepatoprotekcyjne. Polega to na ochronie watroby przed uszkodzeniami poprzez przeciwdziałanie induktorom uszkodzeń watroby, do których należa metale ciężkie, czy długotrwałe spożywanie alkoholu (JIRÁSEK 2014). Diarylheptanoidy stymulują też aktywność jądrowego czynnika transkrypcyjnego NF-kappaB, który reguluje geny odpowiedzialne za proliferację komórek bioracych udział w reakcji zapalnej. Poprzez hamowanie aktywności tego czynnika wykazują właściwości przeciwzapalne (RAJAGANAPATHY i współaut. 2013).

\section{WPEYW CORYLUS AVELLANA NA FUNKCJONOWANIE UKŁADU SERCOWO-NACZYNIOWEGO}

Wiele chorób układu sercowo-naczyniowego wynika $z$ nieprawidłowej diety. Szczególnie szkodliwe działanie ma tłuszcz, który często dostarczany jest nie tylko w nadmiarze, ale także w nieprawidłowej formie. Codzienna dieta przeciętej osoby w Europie czy Ameryce jest bogata w nasycone kwasy tłuszczowe. Takie odżywianie prowadzi do otyłości, chorób układu krążenia, a nawet nowotworów. Dodatkowo, w naczyniach odkładane sa lipoproteiny o niskiej gęstości potocznie nazywane "złym cholesterolem". Prowadzą do takich chorób, jak miażdżyca czy zawał mięśnia sercowego (ACHREMOWICZ i SZARY-SWORST 2005). Orzechy laskowe, chociaż wydaja się być kaloryczna przekaska, sa bardzo zdrowe. Ponad 90\% tłuszczu dostarczanego $z$ nich do organizmu to nienasycone kwasy tłuszczowe, a $80 \%$ tej wartości to jednonienasycone kwasy tłuszczowe. Orzechy sa więc najbogatszym źródłem jednonienasyconych kwasów tłuszczowych. Ich działanie polega na redukcji peroksydacji lipidów w aorcie, watrobie, a nawet osoczu krwi. Powoduja także spadek poziomu „złego cholesterolu” w aorcie (HATIPOĞLU i współaut. 2004), a regularne spożywanie około $40 \mathrm{~g}$ orzechów prowadzi do spadku poziomu lipoprotein o niskiej gęstości. Zmniejsza wykorzystanie nasyconych tłuszczów, a zwiększa wykorzystanie jednonienasyconych kwasów tłuszczowych jako źródła energii dla organizmu (MERCANLIGIL i współaut. 2007). W orzechach laskowy, poza jednonienasyconymi kwasami tłuszczonymi, występuja również wielonienasycone kwasy tłuszczowe, chociaż ich zawartość jest znacząco niższa. Orzechy leszczyny pospolitej w swoim składzie zawieraja mieszaninę wielonienasyconych kwasów tłuszczowych: linolenowego i a-linolenowego oraz kwasu oleinowego. Taka mieszanina $\mathrm{w}$ diecie zmniejsza ryzyko choroby niedokrwiennej serca, a także wpływa pozytywnie na profil lipoprotein, co obniża ryzyko miażdżycy (DYBKowSKA 2015).

\section{PODSUMOWANIE}

Leszczyna pospolita jest bardzo dobrym źródłem różnych zwiazków o działaniu prozdrowotnym między innymi kardioprotekcyjnym. Większość ich kumuluje się w orzechach, które dostarczaja do organizmu kwasy tłuszczowe nienasycone, liczne witaminy i mikroelementy. W przemyśle farmaceutycznym i kosmetycznym można wykorzystać także liście i korzenie ze względu na obecność związków fenolowych, w tym diarylheptanoidów.

$$
\text { Streszczenie }
$$

Orzechy leszczyny pospolitej w swoim składzie zawieraja przede wszytskim nienasycone kwasy thuszczowe. Dodatkowo sa dobrym źródłem witaminy E. Dostarczają też innych mikro i makroelementów niezbędnych w diecie. Zwiąki te wpływaja na prawidłowe funkcjonowanie organizmu poprzez aktywność antyoksydacyjna, zapobieganie peroksydacji lipidów i obniżenie poziomu cholesterolu frakcji LDL. W pozostałych organach leszczyny pospolitej znajduja się związki fenolowe, w tym diarylheptanoidy, które także wykazuja pozytywny wpływ na zdrowie człowieka.

\section{LITERATURA}

ACHREMOWICZ K., SZARY-SWORST K., 2005. Wielonienasycone kwasy tłuszczowe czynnikiem poprawy stanu zdrowia człowieka. Zywność Nauka Technoogia Jakość 3, 23-25.

CiEMNIEWSKA-ŻYTKIEWICZ H, KRYGIER K., BRYŚ J., 2014. Wartości odżywcze orzechów oraz ich znaczenie $w$ diecie. Postęp Techniki Przetwórstwa Spożywczego 1, 90-96.

CiemniewsKa-ŻYTKIEWICZ H., Verardo V., PASINI F., BRYŚ J., KOCZOŃ P., CABONI M. F., 2015. Determination of lipid and phenolic fraction in 
two hazelnut (Corylus avellana L.) cultivars grown in Poland. Food Chem. 169, 615-622.

CONTINI M., FRANGIPANE M. T., MASSANTINI R., 2011. Antioxidants in hazelnuts. [W:] Nuts and seeds in health and disease prevention. Preedy V. R., Watson R. R., PATEL V. B. (red.). Academic Press, 611-652.

Delgado T., Malheiro R., Pereira J. A., RamalHOSA E., 2010. Hazelnut (Corylus avellana L.) kernels as a source of antioxidants and their potential in relation to other nuts. Industr. Crops Products. 11, 621-626.

DYBKOWSKA E., 2015. Rola kwasów tłuszczowych $w$ żywieniu $i$ zdrowiu człowieka. [W:] Znaczenie racjonalnego żywienia $w$ edukacji zdrowotnej. WOLSKA-ADAMCZYK A. (red.). Wydawnictwo Wyższej Szkoły Infrastruktury i Zarządzania, Warszawa, 173-182.

HatipoĞLU A. I., KANBAĞLI O., BALKAN J., KÜÇÜK M., CEVIKBAŞ U., AYKAÇ-TOKER G., BERKKAN H., UYSAL M., 2004. Hazelnut oil administration reduces aortic cholesterol accumulation and lipid peroxides in the plasma, liver, and aorta of rabbit fed in high-cholesterol diet. Biosci. Biotechnol. Biochem. 68, 2050-2057.

JIRÁSEK P., 2014. Synthesis of natural and non-natural diarylheptanoids and evaluation of their neuroprotective activity. Rozprawa doktorska, der Fakultät für Chemie und Pharmazie der Universität Regensburg.

KARAMAĆ M., 2009. Chelation of $\mathrm{Cu}$ (II), $\mathrm{Zn}$ (II), and $\mathrm{Fe}$ (II) by tannin constituents of selected edible nuts. Int. J. Mol. Sci. 10, 5485-5497.

LEWKowicz-Mosiev T. 2012. Rośliny lecznicze. Leksykon. Świat Ksiażki, Warszawa.

LiEw S. C., 2016. Folic acid and diseases- supplement it or not. Rev. Assoc. Med. Bras. 62, 90-100.
MANZARDO A. M., 2015. Thiamine deficiency and alcoholism psychopathology. [W:] Molecular aspect of alcohol and nutrition. PATEL V. B. (red.). Elsevier Science \& Technology, 85-94.

Matuszkiewicz W., Sikorski P., SzWed W., WierzBA M., 2015. Lasy i zarośla. Ilustrowany przewodnik. PWN, Warszawa.

Mercanligil S. M., Arslan P., Alasalvar C., OKUT E., AKGU"L E., PINAR A., GEYIK P., TOKGO"ZOG LU L., SHAHIDI F., 2007. Effects of hazel-enriches diet on plasma cholesterol and lipoprotein profiles in hypercholestelemic adult men. Eur. J. Clin. Nutr. 61, 212-220.

RAJAGANAPATHY B. R., THIRUGNANAM K., SHANMUGaNATHAN M. V., SingaraVElU A., SUBADHRA L. B., 2013. Molecular basis of the anti-inflammatory potential of a diarylheptanoid in murine macrophage RAW 264.7 cells. Adv. Biol. Chem. 3, 541-548.

READERSTORFF D., WYSS A., CALDER P., WEBER P., EGGESDORFER M., 2015. Vitamin $E$ function and requirement in relation in PUFA. Brit. J. Nutr. 114, 1113-1122.

Slatnar A., Mikulic-Petkovsek M., Stampar F., VEBERIC R., SOLAR A., 2014. HPLC-MSn identification and quantification of phenolic compounds in hazelnut kernels, oil and bagasse pellets. Food Res. Int. 64, 783-789.

YÜCESAN F. B., ÖREM A., KuRAL B. F., ÖREM C., TURAN I., 2010. Hazelnut consumption decreases the susceptibility of $L D L$ to oxidation, plasma oxidized LDL level and increases the ratio of large/small LDL in normolipidemic healthy subjects. Anatolian J. Cardiol. 10, 28-35.

KoSMOS Vol. 67, 3, 643-646, 2018

\author{
Agata Rolnik, BeAta Olas
}

Department of General Biochemistry, Institute of Biochemistry, Faculty of Biology and Environmental Protection, University of Lodz, Pomorska 141/143, 90-236 Eódż, E-mail: agarolnik@gmail.com

\title{
HAZELNUTS AND OTHER ELEMENTS OF HAZEL (CORYLUS AVELLANA) AS A RICH SOURCE OF HEALTH- PROMOTING COMPOUNDS
}

\section{Summary}

Hazelnuts of common hazel (Corylus avellana) are mainly composed of unsaturated fatty acids. In addition, they are a good source of vitamin E. They also provide other micro and macro elements needed in the diet. These compounds affect the proper functioning of the body by their antioxidant activity, prevention of lipid peroxidation and lowering LDL fraction of cholesterol. In other parts of the common hazel there occur also phenolic compounds, like diarylheptanoids, which also have a positive effect on the human health. 